\section{Брендинг \\ Ивановской \\ области \\ как проблема \\ и процесс}

\section{Феликс Каган}

История брендинга территорий как направления исследований началась в конце XX века с публикации в 1993 году монографии крупнейших маркетологов Ф. Котлера, К. Асплунда, И. Рейна и Д. Хайдера. Спустя 7 лет эта монография была переведена на русский язык и издана как «Маркетинг городов. Привлечение инвестиций, предприятий, жителей и туристов в города, коммуны, регионы и страны Европы» [Котлер и др., 2005].

В 1998 году британский независимый политический консультант С. Анхольт впервые использовал термин «национальный бренд", приравняв тем самым страны к фирмам и торговым маркам их товаров и услуг. В начале XXI века он развил свои идеи, создав концепцию конкурентной идентичности страны, основанную на сочетании показателей состояния шести ее сфер - туризма, экспорта, политики, инвестиций, культуры и человеческого капитала [Анхольт, Хильдрейт, 2010; Анхольт, 2004].

Идеи Анхольта получили широкое распространение, а его "шестиугольник национальных брендов» стал отправной точкой для многих авторов, исследовавших бренды разных территорий-стран, регионов, городов, местностей

В России 1990-2000-х годов, переживавшей переход от плановой экономики советского периода к свободному рынку с его конкурентной борьбой, новые реалии осознавались постепенно. Регионы, которые в СССР были просто частями большой страны, где экономика и социальная жизнь жестко определялись единым государственным планом, в новых условиях начинали обретать некоторую самостоятельность. Они становились субъектами серьезной конкурентной борьбы за федеральные средства, инвестиции, трудовые ресурсы, известность, туристические потоки и т.д.
Каган Феликс Иосифович, кандидат физико-математических наук, руководитель комплекса музейно-выставочных и ресурсных центров Ивановского государственного политехнического университета; доцент кафедры информационных технологий и сервиса Ивановского государственного политехнического университета; заслуженный работник культуры РФ; Российская Федерация, 153000, Иваново, Шереметевский проспект, д.21, тел.: +7903 8796940 E-mail: fik35@mail.ru

Статья намечает возможный подход к ребрендингу Ивановской области в условиях комплексного постсоветского кризиса. В 1990-е годы регион оказался в сложнейшей ситуации, отягощенной острыми социально-экономическими и демографическими проблемами, возникшими в перестроечный и постперестроечный период на фоне системного кризиса текстильной отрасли страны. Тяжесть кризисной ситуации усугублялась моноотраслевым характером развития региона, занимавшего ведущее положение в текстильной отрасли в масштабах страны на протяжении почти четырех столетий. Положение начало выправляться лишь недавно, поэтому приобрела актуальность проблема ребрендинга региона.

При построении бренд-платформь Ивановской области автор опирается на шестиугольник Анхольта, сочетающий показатели состояния шести сфер: (1) архив имиджей/брендов, (2) историко-культурное наследие, (3) бизнес, инвестиции и миграция, (4) въездной и внутренний туризм, (5) человеческий капитал, (6) внутренняя и внешняя политика. Содержательное наполнение этой схемы проводится автором с учетом социально-экономической и историко-культурной специфики Ивановского края. Он выполняет подробный анализ истории образов и позиционирования Ивановской области на протяжении XVII-XX веков, что позволяет задать историческую глубину анализу текущего состояния и перспектив развития региона. Намечаются возможные пути развития его туристической сферы.

Ключевые слова: Ивановская область; брендинг региона; бренд-платформа; шестиугольник Анхольта

Цитирование: Каган Ф.И. (2021) Брендинг Ивановской области как проблема и процесс // Городские исследования и практики. Т.6. № 1. С.6-22. DOI: https://doi.org/10.17323/ usp6120216-22 
1. Архив имиджей/брендов

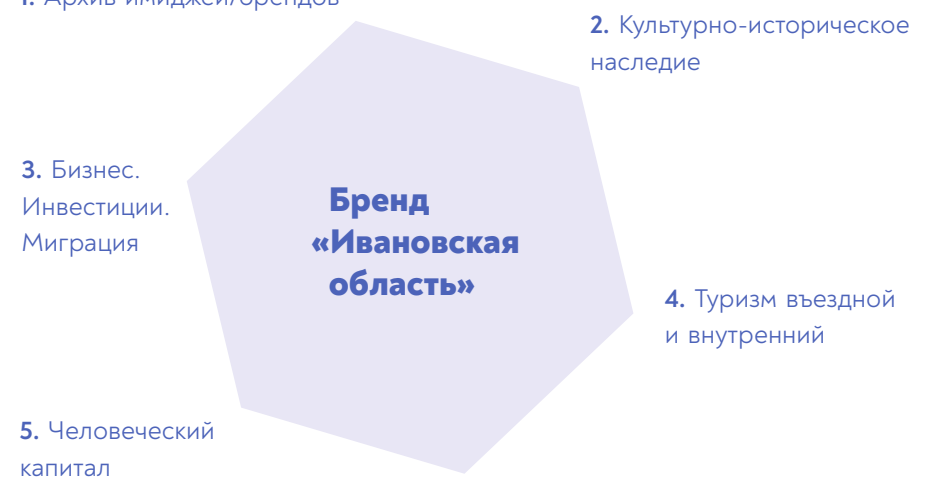

6. Политика внешняя

и внутренняя

РИС. 1. Бренд

«Ивановская

область»

(в соответствии

с шестиугольником

С. Анхольта)

Источник:

построено авто ром.
В этой статье мы рассмотрим анализ имиджей/брендов Ивановской области былых времен и некоторые подходы к ее ребрендингу. В основе этих построений20-летний опыт автора и его коллег в разработке и реализации:

- образовательных проектов подготовки кадров для социально-культурного сервиса и туризма на базе Ивановского текстильного института (в дальнейшемИвановской государственной текстильной академии и Ивановского государственного политехнического университета);

- проектно-внедренческой деятельности в этой сфере в Иванове и Ивановской области [Каган, Белугина, 2013].

Системно-образующей основой исследования является шестиугольник Анхольта, содержательное наполнение которого выстроено нами с учетом социально-экономической и историко-культурной специфики Ивановского края, начиная с периода славянской колонизации этой территории (IX-XI века) до настоящего времени.

Иными словами, мы рассматриваем в качестве бренд-платформы Ивановской области шесть ее сфер в их специфических проявлениях на временно́м промежутке порядка тысячи лет. Это позволяет отслеживать не только перемены экономического, социального и культурного порядков, но и процессы формирования коренного населения Ивановского края.

Приведенная на рис. 1 схема предполагает последовательное рассмотрение следующих пунктов:

- исходные предпосылки развития территории нынешней Ивановской области, начиная со времен славянской колонизации населенных финно-угорскими племенами земель и далее в ходе последовательной смены ее социальноэкономического положения, административного статуса, трансформаций ее населения, идентификации и самоидентификации территории;

- важнейшие жизненные сферы территории - историко-культурное наследие; бизнес, инвестиции, миграция; туризм въездной и внутренний; человеческий капитал; внешняя и внутренняя политика.

\section{1. Архив имиджей/брендов}

\section{1. Географическое положение, транспортная доступность, природный потенциал}

Ивановская область занимает специфическое и выгодное географическое положение в ареале, который соотносится с Верхней Волгой и ориентирован на современный туристический кластер «Золотое кольцо России». Будучи одним из регионов Центрального федерального округа, она является его восточной окраиной, непосредственно соседствующей с Нижегородской областью, северо-западной окраиной Приволжского федерального округа. С введением в эксплуатацию автомобильного моста через Волгу в районе Кинешмы появилась реальная перспектива возникновения мощного автомобильного потока, который будет следовать через Ивановскую область по кратчайшему пути между центральными областями России и северными и северовосточными территориями страны.

Отметим также, что Ивановская область находится в непосредственной близости от Московской агломерации - крупнейшего в России макроэкономического региона и межрегионального центра социальноэкономического развития и притяжения центральной части России, что является серьезным фактором ее экономического развития как перспективного постиндустриального и туристско-рекреационного региона.

Центр Ивановской области, город Иваново, находится в трех-четырех часах езды до Москвы и Нижнего Новгорода и в полутора-двух часах - до основных центров «Золотого кольца»: Ростова, Ярославля, Костромы, Владимира, Суздаля, Плеса, Палеха.

Благодаря усилиям правительства Ивановской области в последние годы был сделан серьезный прорыв в выведении 
транспортной доступности региона на современный уровень. Запуск скоростных поездов «Ласточка» позволил сократить время в пути между Ивановом и Москвой практически вдвое. Ведутся активные работы по созданию современных автодорог до Нижнего Новгорода, Ярославля, а также по ремонту важнейших внутренних дорог региона. Восстанавливается участие волжских городов Плеса, Кинешмы и Юрьевца в круизном туризме. Интенсивно развивается сеть прямого авиасообщения Иванова с Москвой, Санкт-Петербургом и рядом крупных городов и курортных центров России.

Что касается природного потенциала региона, то следует отметить, что половина его территории покрыта лесами, причем почти на 90\% сосной, елью и березой. Важными составляющими природного потенциала являются Клязьминский и Заволжский заказники.

По территории Ивановской области на протяжении почти 180 км протекает река Волга, здесь она образует Горьковское водохранилище. При этом левый берег Волги от Плеса до Юрьевца обращен точно на юг, что серьезно увеличивает рекреационную ценность этой территории. Многоводные левобережные притоки Волги с поросшими лесом берегами - Кистега, Локша, Колдома, Мера, Нодога - дают прекрасные возможности для развития водного туризма и рекреации. Горьковское водохранилище, Волга и ее правобережные притоки - Кинешемка и Елнать - представляют собой удобную акваторию для яхтинга и водно-моторных видов спорта. А левобережные притоки Клязьмы-Нерль и Лух - давно уже облюбованы любителями путешествий на байдарках. Всего же в пределах Ивановской области протекает порядка 160 достаточно крупных рек. На ее территории около 150 лесных озер, высокая экологическая чистота которых создает прекрасные условия для рекреации и туризма.

Даже из этого краткого описания видно, что Ивановская область обладает мощным потенциалом для развития успешной туристско-рекреационной зоны, ориентированной, прежде всего, на жителей Московской агломерации и крупных городов Центрального, Северо-Западного и Приволжского федеральных округов (подробнее см. [Каган, 2008]).

\section{2. Штрихи к социально-психологической характеристике коренного населения региона}

Как свидетельствуют историки (см., напр., [Скрынников, 1997]), славяне появились на Верхней Волге в IX-X веках нашей эры. C северо-запада пришли сюда новгородские словене, а с запада и юго-западакривичи. Причиной массовой миграции кривичей послужили постоянные угрозы для заселенных ими территорий со стороны кочевых племен Великой степи. Более южные по отношению к Новгородчине земли Верхней Волги были привлекательны для новгородских словен в связи с необходимостью освоения новых земель для решения продовольственных проблем, особенно острых в неурожайные годы.

Славяне застали здесь малочисленные племена мерян, относившихся к финноугорской группе. Славянская колонизация была мирной, так что в результате межэтнических браков постепенно сложилось средневековое население этой территории. При этом новгородские словене привнесли с собой опыт искусных ремесленников-ткачей, плотников, кузнецов, гончаров, кожевников, а также опыт торговых людей, способных совершать далекие поездки. В лице кривичей осваиваемый славянами регион приобрел переселенцев, искушенных в земледелии и содержании домашнего скота. Память же о мерянском населении Верхней Волги

сохранилась в многочисленных дошедших до нашего времени гидронимах и топонимах [Тяпков, 2018].

B XIII-XIV веках население нынешней территории Ивановской области пополнилось спасавшимися в ее лесах от монголотатарского нашествия жителями Суздальских земель. Вследствие этого будущий Ивановский край обрел действующие и поныне центры иконописи в Палехе и Холуе, в советское время прославившиеся также как центры лаковой миниатюры.

Следующие XV и XVI века - это время возвышения Москвы и образования Московского централизованного государства. Эти столетия прошли под знаком борьбы Великих князей Московских и Государей всея Руси Ивана III Великого, Василия III Ивановича и Ивана IV Грозного с Новгородской боярской республикой, ее традициями вершить свои главные дела не по воле князя-самодержца, а по решению Новгородского веча. Случались здесь и военные противостояния, и массовые репрессии, в частности насильственное 
Село Иваново - село «набойщиков», центр «рассеянной текстильной мануфактуры»

Село Иваново, город Иваново-Вознесенск - «русский Манчестер», "столица царства ивановских ситцев»

Город Иваново-Вознесенск получил статус центра новой Иваново-Вознесенской губернии («красной губернии»

Город Иваново-Вознесенск - центр Ивановской промышленной области («третья пролетарская столица»)

Город Иваново - центр Верхне-Волжского Совнархоза

Город Иваново - столица текстильного края, родина первого Совета

Город Иваново - город трудовой доблести

\section{Период}

XVII-первая половина XIX века

1864-1917 годы

1918-1929 годы

1929-1936 годы

1963-1965 годы

1960-1980-е годы

С 2020 года
ТАБЛИЦА 1. Периоды, когда Ивановский край занимал те или иные лидерские позиции Источник: данные автора. переселение части своенравных новгородцев на верхневолжские территории, ставшие северо-восточной окраиной Московского царства и местом ссылок. Вдобавок территория эта стала рассматриваться как стратегический плацдарм для расширения Московии, прежде всего с целью контроля над Волгой как важнейшим торговым путем к странам Востока, а далее с выходом на Урал и в Сибирь, и превращения Московского царства в крупнейшее государство Евразийского континента.

Именно с этими геополитическими устремлениями связано основание крепостей, ставших городами Ивановской области,-Плеса, Юрьевца, Кинешмы, Шуи и Луха.

Вполне резонно предположить, что присущие новгородцам предприимчивость, решимость, некоторая авантюрность и склонность к разнообразным ремеслам сделали возможным создание в селе Иваново, причем усилиями крепостных крестьян, сначала текстильных мануфактур, а затем и фабрик. В результате село Иваново, а затем и город Иваново-Вознесенск стали промышленным центром, сравнимым в сознании современников с текстильным Манчестером в Англии.

Отметим, что подобные соображения приведены в одном из первых историкокультурных исследований феномена "русского Манчестера», выполненным представителем известнейшей фабрикантской династии Я. П. Гарелиным, бывшим к тому же серьезным просветителем, благотворителем, инициатором создания города Иваново-Вознесенска и даже его главой. В его знаменитом сочинении читаем: «Нужно припомнить эпоху двух Иванов, III и IV, личности которых в народ- ном представлении слились в одного Ивана Грозного, вспомнить упорную борьбу первого с Великим Новгородом и расселение обоими государями чуть не всего Новгородского люда по различным областям тогдашней Руси, причем особенно много Новгородцев отправлено было в Суздальскую область, в состав которой входил и Шуйский уезд, - нужно припомнить все это, и нам возможно будет объяснить, каким образом засел здесь деятельный, энергичный народ, вызвавший такую кипучую жизнь, которая поставила село Иваново в ряды первых по мануфактурной промышленности» [Гарелин, 1884]. Добавим к этому, что здесь же Я. П. Гарелин свидетельствует и о том, что в начале XIX века «Иваново представляло сплошное раскольничье поселение». А это важное дополнение к социально-психологическому «портрету» коренных ивановцев.

\section{3. От имиджа - к имиджу, от имиджа - к бренду}

Далее мы кратко рассмотрим трансформации в истории Ивановского края, которые, по нашему мнению, позволяют говорить, что эта территория отличается устойчивым стремлением к лидерству, к авангардной роли.

Здесь требуются некоторые комментарии

1. В XVII веке домашнее прядение и ткачество льняных холстов было широко распространено в Верхнем Поволжье ввиду доступности и дешевизны хорошо растущего на этих землях льна. Предприимчивые крестьяне села Иваново предпочли трудоемкому ручному прядению и ткачеству скупку неотделанных льняных холстов в окрестных селах и деревнях, их крашение, ручную набойку рисунка с помощью деревянных манер и продажу готовых льняных тканей с хорошей прибылью. Иваново становится богатым торгово-промысловым селом. K середине XVIII века здесь образовался слой разбогатевших «капиталистых крестьян», которые стали заводить текстильные мануфактуры с применением наемного труда, а затем и первые фабрики с применением машин. Население села быстро росло, так что к концу XVIII века его численность почти в 3,5 раза превосходила население уездного города Шуи. На рубеже XVIII и XIX веков в селе Иваново происходит переход к производству преиму- 
щественно хлопчатобумажных тканей. А в первой половине XIX века распространяется так называемая «рассеянная мануфактура», когда ивановские владельцы ситценабивных фабрик стали раздавать в окрестные села готовую пряжу для основы и утка ткачам-надомникам и мелким хозяевам, "светелочникам». И затем получать от них готовую суровую хлопчатобумажную ткань - миткаль, который в результате отделки, крашения и печати рисунков превращался в ситцы [Балдин, Семененко, 1996].

2. Отмена крепостного права в 1861 году создала среди прочего возможности для притока рабочей силы в текстильное производство, бурно развивающееся в селе Иваново и Вознесенском Посаде, что образовался напротив села, на левом берегу реки Уводи. Пройдя этапы промышленного переворота, текстильное производство расцвело настолько, что известный экономист, академик Санкт-Петербургской академии наук В.П. Безобразов в статье, опубликованной в 1864 году в "Отечественных записках», назвал село Иваново "русским Манчестером». В 1871 году из села Иваново и Вознесенского Посада был образован город Иваново-Вознесенск, который стали привычно именовать "русским Манчестером». На рубеже XIX и XX веков произведенные в ИвановоВознесенске ткани получили ряд высоких наград на Международных и Всероссийских промышленных выставках. Утвердился историко-культурный феномен «ивановские ситцы». Кроме того, на территории Верхней Волги фактически возник Иваново-Вознесенский промышленный район с главной отраслью-хлопчатобумажной промышленностью. «Русский Манчестер» при этом стал восприниматься как столица "ситцевого царства» [Балдин, Мокеeв, 2006].

3. В 1918 году при деятельном участии М.В. Фрунзе, который удерживал в своих руках партийное, хозяйственное и военное руководство фактически всем Иваново-Вознесенским промышленным районом, была учреждена новая Ивановская губерния («красная губерния») с центром в Иваново-Вознесенске, вобравшая в себя наиболее развитые в промышленном отношении территории Владимирской и Костромской губерний (см., напр., [Тихомиров, 2011]).

4. В 1929 году была создана Ивановская промышленная область с центром в Иваново-Вознесенске, вобравшая в себя четыре губернии - Владимирскую, Ивановскую, Костромскую и Ярославскую. Впоследствии был проведен ряд всесоюзных архитектурных конкурсов, направленных на коренное изменение облика Иваново-Вознесенска. Благодаря этому город теперь обладает значительным архитектурным наследием в традиции конструктивизма, но утратил большинство памятников храмовой архитектуры. В связи с этими событиями и надеждами на обретение Иваново-Вознесенском высокого статуса в стране победившего пролетариата город стали все чаще именовать «третьей пролетарской столицей» после Ленинграда, колыбели пролетарской революции, и Москвы, столицы пролетарского государства СССР. Велись даже разговоры о возможном преобразовании Иваново-Вознесенска в столицу РСФСР [Там же].

5. В 1957 году была предпринята попытка реформировать систему управления социально-экономической жизнью СССР путем образования на всей территории страны системы из Совнархозов - Советов народного хозяйства. В 1963 году в результате их укрупнения был создан Верхне-Волжский Совнархоз с центром в Иванове, в состав которого вошли все те же Владимирская, Ивановская, Костромская и Ярославская области. Эта реформа закончилась в 1965 году после отстранения от власти Н. С. Хрущева [Там же].

6. В 1960-1980-е годы Ивановская область позиционировала себя как «текстильный цех страны», а город Иваново неизменно рассматривался как «столица текстильного края». Одновременно были приложены большие усилия, чтобы представить в массовом сознании Иваново как «родину первого Совета». К празднованию 70-летия образования в Иваново-Вознесенске «первого общегородского рабочего Совета», прообраза советской власти, был реализован впечатляющий комплекс работ по созданию зримого образа этой глобальной идеи-монументы, мемориалы, мемориальные доски, музей первого Совета, литературные и музыкальные произведения, переименования и т.д. Эта попытка создать бренд города Иванова как «родины первого Совета», а Ивановской области - как «края революционных традиций» ныне является 


\begin{tabular}{|c|c|c|c|}
\hline Регион & $\begin{array}{r}\text { Количество объ- } \\
\text { ектов культурно- } \\
\text { го наследия }\end{array}$ & $\begin{array}{r}\text { Площадь } \\
\text { региона, } \\
\text { тыс. кв. км }\end{array}$ & $\begin{array}{r}\text { Количество } \\
\text { объектов } \\
\text { на тыс. Кв. Км }\end{array}$ \\
\hline Санкт-Петербург & 10087 & 1,4 & 7205 \\
\hline Москва & 8395 & 2,6 & 3229 \\
\hline Ивановская область & 3298 & 21,4 & 154 \\
\hline Ярославская область & 5426 & 36,2 & 150 \\
\hline Московская область & 6034 & 44,3 & 136 \\
\hline Владимирская область & 3628 & 29,1 & 125 \\
\hline
\end{tabular}

ТАБЛИЦА 2.

Рейтинг регионов РФ по плотности распределения объектов культурного наследия Источник: [Площади..., 2019].

лишь достоянием нашей локальной истории [Там же].

Есть в архиве ивановских имиджей/брендов сюжет воистину курьезный. Любой случайный иногородний собеседник, узнав, что его визави из Иванова, тут же отреагирует: «Так вы из Иванова, города невест?» Такой узнаваемости может позавидовать самый раскрученный бренд. При этом оба собеседника, скорее всего, не знают, какова подоплека такого «всем известного» определения города Иванова. И уж тем более не знают (и не хотят знать), какие затраты понес город, продвигая этот бренд в массовое сознание.

Подоплека же такова. В послевоенное время в Иванове возникла большая диспропорция между мужчинами и женщинами. Причин этому было две: потери среди мужского населения в годы войны и преимущественно женские профессии (прядильщицы, ткачихи и т.д.) в текстильной промышленности, которая доминировала в городе. Но в 1950-е годы здесь построили несколько машиностроительных предприятий, и действительно серьезная демографическая проблема была существенно смягчена.

Что же касается славы Иванова как «города невест», то здесь решающую роль сыграла песенка, исполненная Андреем Мироновым в фильме 1981 года «Честный, умный, неженатый». В ней трижды повторяется последняя строчка припева: «А Иваново - город невест».

Самое удивительное, что «отцам города» за прошедшие с тех пор 40 лет так и не пришла в голову мысль, что можно (и должно, на наш взгляд) использовать эту бесплатно упавшую с небес известность города как туристический бренд. Разумеется, при этом необходимы были бы сообразительность и усилия по созданию в городе достойной и оригинальной "свадебной инфраструктуры» на стыке многоликого свадебного сервиса, индустрии моды, дизайна, музейного дела, туризма и гостеприимства. И все это на радость невестам и их избранникам, которых в Иванове и за его пределами великое множество.

Заметим для полноты обзора, что в постперестроечное время было несколько безуспешных попыток построить новые бренды Иванова: "русский Кембридж», "русский Лас-Вегас», «молодежная столица Европы», «самый советский город», «столица торговли и развлечений», "столица нестоличной моды». Но в силу их несомненной надуманности или по иным причинам ни один из этих брендов не сложился.

\section{2. Историко-культурное наследие}

\section{1. Рейтинг регионов по культурному наследию}

В рейтинге регионов России по обеспеченности цифровой открытости объектов культурного наследия Ивановская область занимает высокое 12-е место из 85 регионов [Рейтинг.., 2018]. Если же сравнивать регионы по плотности распределения объектов культурного наследия, то, поделив число объектов на площадь региона [Площади..., 2019], мы получаем следующую картину.

Из табл. 2 видно, что Ивановская область находится на третьем месте после Санкт-Петербурга, культурной столицы России, и Москвы, столицы Российской Федерации. Причем она неожиданно опережает при этом Владимирскую, Костромскую, Московскую и Ярославскую области, своих партнеров по туристическому маршруту «Золотое кольцо России».

Как и во всей России, многие памятники историко-культурного наследия в Ивановской области находятся в неудовлетворительном состоянии. Тем не менее гости области заметят значительное изменение этой ситуации в Иванове, Кинешме, Шуе, Плесе, Палехе, Холуе, Нижнем Ландехе и других исторических поселениях Ивановской области - здесь действует основательная программа по приведению в порядок малых городов региона.

Отметим также вполне оригинальный музейный комплекс Ивановской области. Это единственные в своем роде Музей промышленности и искусства имени Д. Г.Бурылина и Музей ивановского ситца в Иванове, Музей И.И. Левитана и Музей пейзажа в Плесе, Музейный центр А. А. Тар- 
ковского в Юрьевце, Музей К. Д. Бальмонта в Шуе, Музей изобретателя электросварки Н. Н. Бенардоса в Лухе.

Широкую известность в России и за рубежом имеют центры иконописи и лаковой миниатюры в Палехе и Холуе, расположенные здесь государственные музеи соответственно палехского и холуйского искусства, а также центры ручной вышивки и строчки, действующие в ряде исторических поселений области.

\section{2. Социокультурное проектирование}

Туристское брендирование играет существенную роль в процессе ребрендинга территории. Не случайно в рассматриваемом нами шестиугольнике Анхольта туризм въездной и внутренний выступает в роли одной из его вершин.

Далее мы предлагаем ряд принципиально важных, с нашей точки зрения, направлений социокультурного проектирования в масштабах Ивановской области, которые призваны обеспечить существенное инфраструктурное и содержательное развитие ивановского туризма.

\subsection{1. Места памяти и знаменитости Ивановского края}

Понятие «место памяти», разработанное французским историком Пьером Нора [Нора, 1999], предполагает помимо некоей пространственно-временной дефиниции символическое воплощение и осознаваемые сообществом культурные смыслы, значимые для этого сообщества и способствующие поддержанию его идентичности.

Согласно ярославскому культурологу Е. А. Ермолину, «местами памяти могут стать любые люди, события, предметы, здания, книги, песни или географические точки, которые окружены символической аурой. Места памяти - всякое значимое единство материального или идеального порядка, которое воля людей или работа времени превратили в символический элемент наследия, включили в ядро памяти общности; то есть достопримечательности, исторически значимые места, национальные праздники, народные герои, памятники и т. п.» [Ермолин, 2007].

С нашей точки зрения, обретение места памяти - это не просто собирание свидетельств о прошлом, а целенаправленное, имеющее авторов создание емкого и зримого образа прошлого, причем созвучного восприятию современных людей.
Достигается это за счет тщательного отбора исторических деталей, их порой неожиданного соотнесения и высвечивания таким образом, чтобы эта совокупность разрозненного превратилась в концентрат смыслов, в красноречивый символ, образ, передающий аромат и дух ушедшего времени, интересный и понятный современным людям. Иными словами, уместно говорить об актуализации культурного наследия [Каган, Белугина, 2013].

В Ивановской области наиболее развитое место памяти сформировано в Плесе вокруг имени художника И.И. Левитана (Левитановский музей с бюстом И.И. Левитана рядом с ним, мемориал «Гора Левитана», Левитановский культурный центр с концертно-выставочным залом «Левитан-холл», культурные акции и экскурсии по левитановским местам).

Достаточно серьезные основания для создания полноценных мест памяти имеются в Иванове (места памяти государственного и военного деятеля М. В. Фрунзе, фабриканта, коллекционера и мецената Д. Г. Бурылина). В Кинешме это место памяти драматурга А. Н. Островского, в Юрьевце-кинорежиссера А. А. Тарковского и архитекторов братьев Л.А., В.А. и А. А. Весниных, в Шуепоэта К. Д. Бальмонта, в Заволжске - астронома Ф.А. Бредихина, в Лухе-изобретателя Н. Н.Бенардоса.

\subsection{2. Бизнес-арт-зона «Русский Манчестер" в Иванове}

В самом центре Иванова поблизости от реки Уводь располагается комплекс зданий бывшей фабрики «Товарищества Куваевской мануфактуры», которая в конце XIX - начале XX века была крупнейшим, наиболее технически оснащенным текстильным предприятием города [Тихомиров, 2011]. В советское время оно именовалось Большой ивановской мануфактурой (БИМ). Сегодня основные корпуса пустуют, а расположенные по периметру вспомогательные здания сдаются в аренду разным учреждениям и небольшим заведениям.

Мы предлагаем создать на основе БИМ бизнес-арт-зону под названием «Русский Манчестер", это будет материальным воплощением в центре города наиболее устойчивого и адекватного его бренда. Вот основные составляющие этого комплекса.

- Музей Куваевской мануфактуры с показом истории развития текстильных технологий.

- Музей Иванов в Иванове [Каган, 2010]. 
- Лофт-отель «Ситцевый рай от фабрикантов Куваевых».

- Хостел-музей «Образцовая куваевская спальня» с экспозицией, посвященной дореволюционной фабричной культуре повседневности.

- Дизайн-центр: ткани, костюмы, интерьеры, ландшафты, арт-объекты.

- Центр социально-гуманитарных исследований: семиотика культуры, социальная психология, социальное проектирование, музейное проектирование, туризм, молодежная культура.

- Творческое объединение «Союз муз»: галерея современного искусства, изостудия, театральная студия, лаборатория видео-арта, камерный концертный зал, кинотеатр под открытым небом.

- Продюсерский фестивальный центр: режиссерско-постановочная группа, лаборатории технического и декорационного обеспечения, мастерская ростовых кукол и др.

- Зоны торговли и сервиса: модные бутики, шоурумы, сувенирные лавки, ресторан, кафе и т. п.

- Зоны отдыха и развлечений.

\subsection{3. Музейный квартал «Вознесенский» в Иванове}

Под «музейным кварталом» мы понимаем относительно компактно расположенный комплекс компонентов городской среды, в котором есть некое историко-культурное единство и преобладают музеи. Вдобавок в этом комплексе должна действовать система мероприятий (охранных, реставрационных, выставочных, экскурсионных, информационных, сервисных) и арт-акций. Все это позволит решать задачи сохранения историко-культурной среды города, ее музеефикации, мемориализации, актуализации и трансляции в историко-культурной и художественной целостности местному населению, экскурсантам и туристам.

Музейный квартал-это реальный синтез двух типов мест:

- места, где культура и искусство транслируются широкой публике (музеи, учреждения музейного типа, туристические и культурно-туристические центры, экскурсионные бюро, издательские центры и средства массовой информации, театрально-зрелищные и досуговые учреждения, предприятия сервиса);

- места, где культура и искусство создаются (мастерские художников, дизайне- ров, архитекторов; исследовательские и ресурсные центры; поэтические, музыкальные и театральные студии; творческие мастерские для создания фестивалей и арт-акций, основанных на синтезе искусств; образовательные учреждения для сферы культуры и искусства).

Музейный квартал необходимо рассматривать как целостное социокультурное пространство, в котором местные жители и гости города получают комплексное информационное и экскурсионное обслуживание. При этом информационное обслуживание предполагает создание в музейном квартале развитой системы навигации, возможностей получения информации через наружную рекламу, информационные щиты как элементы оснащения музеев под открытым небом, аудиогиды и QR-коды, считываемые через гаджеты посетителей квартала и обеспечивающие доступ к соответствующим ресурсам интернета.

Музейный квартал города должен быть насыщен предприятиями сервиса: гостиницами, ресторанами, кафе, барами, сувенирными магазинами и лавками, модными бутиками, магазинами для связанного со спецификой города шопинга, а также зрелищными заведениями.

Таким образом, идея «музейного квартала» рассматривается здесь в широком социокультурном контексте.

На наш взгляд, в Иванове есть пространство, которое удовлетворяет сформулированным выше требованиям [Каган, 2016]. Это достаточно обширная территория, привязанная к двум осям - проспекту Ленина на участке от площади Пушкина до перехода в улицу Фрунзе и набережная по левому берегу Уводи от Театрального до Соковского моста. Сюда также включаются сопрягающиеся с этими осями улицы Карла Маркса, Октябрьская, Калинина, 8 Марта, Громобоя, Жиделева, Шестернина, Батурина и некоторые другие. Поскольку эта территория включает в себя ядро бывшего Вознесенского Посада, который вместе с селом Ивановом дал жизнь городу, естественно предложить для музейного квартала имя «Вознесенский музейный квартал».

На этой территории мы предлагаем создать три новых музея.

- Музей творческого наследия Вячеслава Зайцева, кутюрье с мировым именем, уроженца города Иванова, где он 


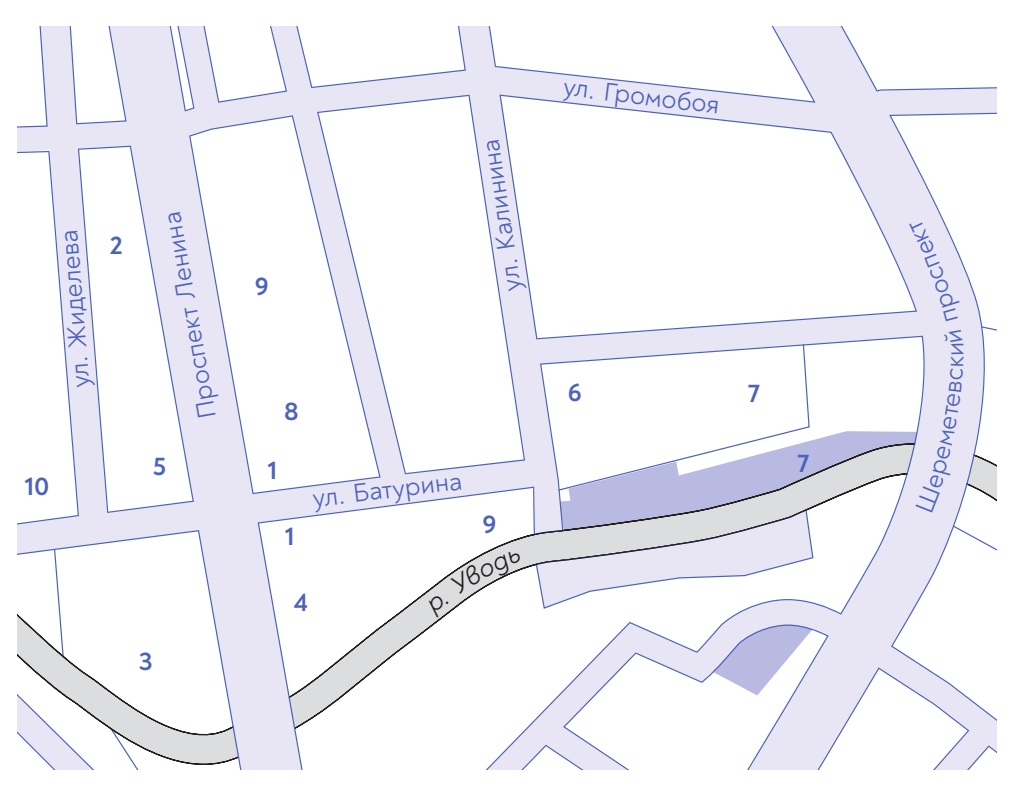

РИС. 2. Музейный квартал «Вознесенский» Источник: [Каган, 2016].

получил среднее профессиональное образование и где на протяжении многих лет под его патронажем проводились фестивали моды «Текстильный салон».

- Музей ивановского цирка им. В.А. Волжанского, уроженца Иваново-Вознесен ска, канатоходца, акробата, эквилибриста, режиссера, конструктора цирковой аппаратуры, Народного артиста СССР.

- Архитектурный музей под открытым небом вдоль проспекта Ленина, основной магистрали города, и прилегающих улиц, где можно увидеть широкий спектр памятников фабричной архитектуры XIX-XX веков, фабрикантских и купеческих особняков, общественных и жилых зданий в традициях эклектики, модерна, неоклассицизма, конструктивизма, советского ампира и постмодерна [Тихомиров, 2011; Тимофеев, 2017].

Еще одно предлагаемое нами новое социокультурное пространство - пешеходная зона Fashion Street. Она представляет собой аллеи вдоль левого берега Уводи от Театрального до подвесного пешеходного моста. Здесь встречаются высокая мода и самая широкая публика на уличных показах новых моделей дизайнеров (одежды, обуви, интерьеров, ландшафтов приусадебных участков и т.д.). Здесь регулярно проводятся акции, которые объединяют людей с общими интересами. Здесь люди отдыхают, развлекаются, усваивают полезные для себя вещи и одновременно даже самоутверждаются. Словом, это пространство культуры повседневности, в котором у горожан исподволь
1. ИКМ им. Д.Г. Бурылина с Музеем ивановского ситца.

2. Областной художественный музей.

3. Бывшая Куваевская мануфактура.

4. Цирк.

5. Ивановское художественное училище

и ДХШ.

6. Корпус ИВГПУ.

7. ТРЦ «Серебряный город» и его парк

аттракционов.

8. Литературный сквер.

9. Гостиницы «Вознесенская» и «Турист».

10. «НИМ Лофт».

формируется свой индивидуальный стиль и то, что именуют стилем жизни.

\section{3. Бизнес. Инвестиции. Миграция}

В 1913 году на долю текстильных фабрик Иваново-Шуйского промышленного района приходилось 25\% всех выпускавшихся в России тканей. Революция 1917 года положила конец развитию промышленности как частного предпринимательства, а последовавшая за ней Гражданская война породила разруху, однако в конце 1920-х годов произошел довольно быстрый подъем национализированного текстильного производства теперь уже в Ивановской промышленной области. Впоследствии в Иванове построили крупнейший меланжевый комбинат, а в области - целый ряд фабрик и комбинатов.

В послевоенное время построили крупнейший в СССР камвольный комбинат, производивший смесовые ткани из шерсти с синтетикой. А в 1970-е годы текстильная промышленность Ивановской области прошла через масштабное техническое перевооружение. Таким образом, к началу перестроечного периода в Ивановской области производилась почти четвертая часть общесоюзного объема тканей, а 43\% населения области работали в сфере текстильного производства, то есть почти было достигнуто предреволюционное положение текстильной отрасли Ивановского региона в масштабах всей страны [Каждый пятый..., 2019].

Кризис 1990-х годов ивановский текстиль пережил крайне тяжело. Общая ситуация, связанная с превратностями пе- 
рестройки, усугубилась тем, что многие из городов Ивановской области были моногородами. В результате Ивановская область из-за своей ярко выраженной моноотраслевой специализации стала одним из самых депрессивных регионов страны.

С начала 2000-х годов прошло 20 лет. После глубокой стагнации ситуация в Ивановской области стала медленно меняться, но настоящие серьезные перемены отчетливо обозначились в последние два года как следствие целенаправленной политики нового состава правительства региона. Согласно информации новостных лент и статистических сборников Ивановостата, текстильная промышленность в Ивановской области сегодня - это более 300 предприятий, годовой оборот которых превышает 200 млрд рублей. В ней трудится 1/3 всех работающих в области. Здесь выпускается 88\% хлопчатобумажных и 75\% трикотажных тканей, производимых в России. Кроме того, в Ивановской области шьется более 1/3 всей производимой в России спецодежды и 69\% всего российского постельного белья. Что касается вклада производства тканей и одежды в бюджет области, то его доля в ВРП региона составила в 2019 году 25,78\% [Там же].

Таким образом, можно утверждать, что Ивановская область уверенно возвращается к былой славе лидера текстильной промышленности страны, впрочем, с некоторой переориентацией на трикотажные полотна и трикотажные изделия, пошив спецодежды и так называемого «домашнего текстиля».

Важно отметить еще три существенные перемены:

- кардинальные технологические сдвиги, связанные с изменением самих принципов работы технологического оборудования, его автоматизацией и использованием цифровых технологий;

- значительное снижение потребности в персонале, порой переход к малолюдным технологиям вследствие автоматизации и цифровизации производства;

- переход многих предприятий отрасли в разряд предприятий малого и среднего бизнеса.

Два последних обстоятельства активизировали усилия правительства области по привлечению инвестиций и улучшению инвестиционного климата в регионе. Так, инвестиции в основной капитал по полному кругу организаций за счет всех источни- ков финансирования в 2019 году выросли на 24,7\% по сравнению с уровнем 2018 года и составили порядка 38 млрд рублей. Создан Фонд развития промышленности Ивановской области. АНО «Агентство по привлечению инвестиций в Ивановскую область» заключило 20 соглашений на сопровождение инвестиционных проектов с потенциальным объемом инвестиций 2 млрд рублей в первые два года реализации и создание более 360 рабочих мест.

Ивановская область вошла в первую десятку регионов страны и стала лидером ЦФО по снижению административного давления на бизнес. В 2019 году она стала лидером национального рейтинга по состоянию инвестиционного климата в номинации «Поддержка малого бизнеса».

Кризис 1990-х годов привел к полному исчезновению в Иванове предприятий текстильного машиностроения - Ивановского завода текстильных машин, Ивановского завода чесальных машин, Ивановского завода испытательных приборов. Это привело к существенной нехватке рабочих мест для мужского населения города, и, как следствие, возникла значительная трудовая миграция мужского населения в Москву для работы вахтовым методом, причем с преимущественной занятостью в непроизводственной сфере и нередко мужчин с высшим техническим образованием.

В то же время сохраняется высокий спрос на рабочих строительных профессий (штукатур, каменщик, плотник, отделочник и другие), водителей, электрогазосварщиков, токарей, электромонтеров. Причем в области есть определенные трудности в трудоустройстве иногородних граждан, поскольку большая часть вакансий предлагается работодателями с заработной платой ниже среднего уровня по Российской Федерации.

\section{4. Въездной и внутренний туризм}

По своему географическому положению, транспортной доступности, природному и историко-культурному потенциалу Ивановская область вполне может позиционировать себя как территорию успешного туристического бизнеса и рекреации. За последние 10 лет приложено немало усилий, чтобы превратить этот потенциал в успешный бизнес. Тем не менее вклад туризма и рекреации в ВРП Ивановской области все еще едва заметен, и это несмотря на немалые усилия правительства области по привлечению федераль- 
ных средств на улучшение транспортной доступности, развитие туристической инфраструктуры и продвижение региона на рынке туристических и рекреационных услуг.

Да, за последние два года есть существенные сдвиги в кардинальном улучшении транспортной доступности региона, в благоустройстве Иванова, малых городов и исторических поселений, в том числе моногородов региона, имеющих несомненную историко-культурную ценность. Да, сделаны успешные шаги по возрождению в регионе волжского круизного туризма. Да, создаются событийные поводы для организации значимых туристических потоков в Ивановскую область. И он, этот поток, превысил 800 тыс. человек, причем 500 тыс. туристических посещений приходится на волжские города Плес, Кинешму и Юрьевец. Да, реализуется, например, масштабный проект по созданию туристического комплекса на базе зданий дворцовых конюшен 1784 года в Гавриловом Посаде. И тем не менее вклад туризма в ВРП региона все еще очень мал.

Причины скромных успехов, по нашему мнению, кроются не столько в неразвитости туристической инфраструктуры, сколько в явно недостаточном внимании к разработке инновационных, конкурентных туристических продуктов и подготовке хорошо обученных и креативных кадров.

Далее мы рассмотрим два направления деятельности, которые представляются нам значимыми для динамичного развития ивановского туризма и которые могут быть полезными для продвижения брендов Ивановского края.

\section{1. Ивановский туризм как межрегиональный туризм}

Въездной и внутренний туризм в России до сих пор развивается преимущественно как туризм региональный. Каждый регион в меру своего понимания и возможностей старается сделать свою территорию максимально привлекательной, а сервис на ней-достойным настолько, чтобы туризм стал наконец не только средством повышения имиджевой привлекательности региона, но и значимым фактором региональной экономики.

Межрегиональные туры сложнее разрабатывать и реализовывать, но у них есть как минимум два стратегических преимущества.
1. Начинаясь, как правило, в столицах или мегаполисах, межрегиональные туры могут давать устойчивые и большие туристические потоки.

2. Направление этих маршрутов из развитых центров в провинцию при условии качественного экскурсионного и анимационного сервиса с опорой на современные мультимедийные и другие цифровые технологии позволит осваивать в туризме более фундаментальную и интересную историко-культурную и иную тематику.

Кроме того, межрегиональные туры естественно использовать для продвижения региональных брендов.

Очень перспективным, по нашему глубокому убеждению, является создание межрегиональных туров вдоль старинных торговых путей. При таком подходе к туризму достопримечательности не просто «нанизываются» на маршрут, а возникает возможность их представления в естественных и часто исторических культурнохозяйственных связях. К тому же есть значительное количество исторических населенных мест (торговых, дворцовых, монастырских сел), которые ныне деградируют только потому, что от них ушли значимые дороги. Туризм - по сути единственный шанс дать таким поселениям новый импульс для возрождения и развития.

Через Ивановскую область пролегали многие старинные торговые тракты: Суздальский (Ростов Великий - Ильинское Гаврилов Посад-Суздаль), Стромынский (Москва - Юрьев-Польский - Суздаль Владимир - Шуя), Галичский (Суздаль Кинешма - Галич), Екатерининский (Суздаль - Шуя - Лух - Юрьевец), Большая Московская дорога на крепость Плес, Аракчеевский (Санкт-Петербург-Ярославль - Нерехта - Середа - Нижний Новгород), Балахонский (Суздаль-Мугреево - Балахна), струговой торговый ход по рекам Теза - Клязьма - Ока - Волга (рис. 3). Разумеется, современные дороги, естественно, где-то расходятся со старинными торговыми трактами, но основные направления сохранились в них до сих пор [Каган, 2020].

Для развития межрегиональных туров через Ивановскую область можно предложить следующую их тематическую типологию.

1. Туры по следам коммуникаций общенационального уровня. 


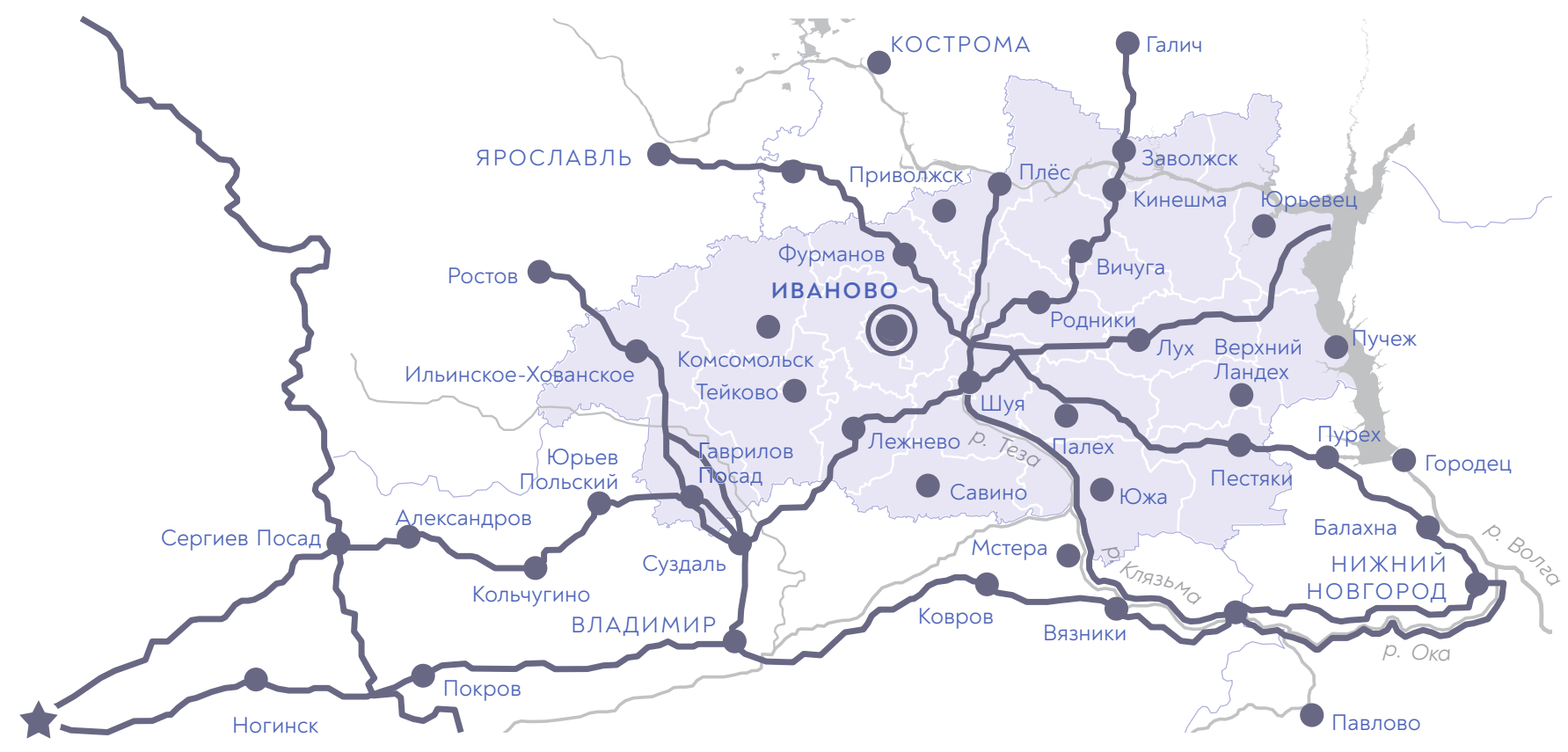

MOCKBA

РИС. 3.

Старинные тракты, проходившие по территории нынешней Ивановской области (Суздальский, Стромынский, Галичский, Екатерининский, Большая Московская дорога, Аракчеевский, Балахонский и струговой торговый ход) Источник: [Каган, 2008].
Примером такого типа межрегионального тура является тур «Из Москвы-к Волге, в Ивановское Залесье, вдоль Владимирского и Екатерининского трактов». Маршрут предлагаемого тура, начинаясь в Москве, проходит по территории трех областей-Московской, Владимирской и Ивановской. С этим маршрутом могут быть связаны значимые события российской истории:

- продвижение Московского царства на северо-восток к Волге с созданием системы русских крепостей (Шуя Лух - Юрьевец) для защиты от иноземных набегов и использования их при военных походах к Волге и вниз по ее течению (Казань, Астрахань);

- путь исхода старообрядцев на Урал и далее в Сибирь (XVII-XVIII века);

- путь промышленного освоения Урала и Сибири (XVII-XIX века).

2. Туры, связанные с историко-культурными явлениями

Пример такого кольцевого межрегионального тура - «Два Андрея: Андрей Рублев и Андрей Тарковский» (МоскваВладимир - Суздаль - Юрьевец - Москва). Этот тур разработан в Ресурсном центре туризма и социокультурной инноватики ИВГПУ [Белугина, 2020]. Его тематика связана с обстоятельствами съемки фильма Тарковского «Андрей Рублев». Но глубинная цель-приобщение туристов к двум культурным кодам России - иконописцу Андрею Рублеву и режиссеру Андрею Тарковскому, жизненные пути которых разделены во времени без малого шестью столетиями

3. Туры, связанные с географическими и историко-культурными явлениями.

Речь здесь может идти, например, о создании перспективного межрегионального тура, связывающего пять знаменитых центров народных художественных промыслов - Палех, Холуй, Мстера, Павловона-Оке, Городец. Эти поселения к тому же расположены по берегам или в непосредственной близости от впадающих друг в друга рек Люлех, Теза, Клязьма, Ока, Волга, составлявших в Средние века водный торговый путь.

4. Туры, связанные с судьбами знаменитостей.

Подобных туров может быть немало, поскольку в судьбах многих широко известных людей столичное и провинциальное многократно пересекаются. Так, напрашивается создание тура «Траектория судьбы великого астронома Ф.А. Бредихина» (Москва - Заволжск-Санкт-Петербург Москва).

5. Туры «по воле исторического случая».

В качестве примера можно привести межрегиональный автобусный тур «С обществом „Добролет“-в историю отечественной авиации» (Москва - Монино Иваново - Чкаловск - Нижний Новгород с. Орехово - Киржач-Москва). В основе тура лежит исторический факт: в 1923 году обществом «Добролет» был организован первый в СССР рейс гражданской авиа- 
ции по маршруту Москва - Иваново-Вознесенск - Нижний Новгород. Мы решили использовать этот «исторический случай» для создания тура, знакомящего с богатейшей историей развития авиации в нашей стране.

\section{2. На пути к ивановскому промышленному туризму}

Ивановский край, бывший и, как теперь выясняется, остающийся лидером текстильной отрасли России, несомненно, может и должен стать территорией развитого промышленного туризма. К тому же здесь удовлетворение любопытства к собственно технологиям изготовления тканей может быть дополнено весьма привлекательным шопингом, причем не только сувенирным, но и вполне прагматическим.

Но особенно важно и неожиданно, что для ивановского промышленного туризма есть замечательный материал об интереснейших, порой драматических судьбах творцов "ситцевого царства», о многочисленных фабрикантских династиях, ведущих свои родословные от крепостных крестьян. Важно заметить, что речь при этом идет не только об Иванове, но и о множестве больших и совсем маленьких населенных пунктов области. Это города Кинешма, Шуя, Вичуга, Тейково, Южа, Фурманов и Приволжск, небольшие поселки Наволоки, Каменка, Старая Вичуга и др.

В Ресурсном центре туризма и социокультурной инноватики ИВГПУ начата разработка комплексной темы «Ситцевые короли Ивановского края: дела фабричные, личные и публичные», которая, по нашему замыслу, должна выйти за пределы только культурно-познавательного туризма, чтобы привнести в промышленный туризм всегда интересное туристам «человеческое начало».

Конечно же, так понимаемый промышленный туризм будет активно способствовать продвижению и областных, и местных брендов. Кроме того, в историях фабрикантов есть много поучительного, в том числе и для молодых людей, мечтающих об открытии собственного дела практически с нуля.

\section{5. Человеческий капитал}

Самая большая проблема, с которой столкнулось новое руководство Ивановской области, - это демографическая ситуация в регионе. В демографическом рейтинге, который подготовили эксперты РИА «Но- вости» на основе данных Росстата за 20172019 годы, Ивановская область заняла 75-е место. Численность населения здесь за три года сократилась на 2,5\%. При этом естественная убыль составила 21200 человек, а миграционный отток - 4800 человек. На 1 января 2020 года численность населения Ивановской области снизилась до 997135 человек, то есть впервые стала менее миллиона человек. К этим тревожным показателям следует добавить тенденции к нарастанию диспропорции в численности мужчин и женщин, а также старение населения региона.

Ясно, что эти демографические показатели сильно коррелируют с уровнем жизни населения, состоянием образования, здравоохранения, культуры. При этом качественная молодежная политика становится задачей номер один. Она более всего должна быть направлена на создание условий для удержания молодежи в родных местах. Это требует решения проблемы образования, воспитания, создания привлекательных рабочих мест, решения жилищной проблемы для молодых семей, создания комфортной городской среды, развития молодежной культуры, спорта, здорового и интересного досуга, смягчения разрыва между столичным и провинциальным уровнями жизни.

Особую остроту в современных условиях приобретает состояние высшего образования в регионе. Высшая школа в городе Иванове, которой еще совсем недавно мы гордились («Иваново - город студентов!») переживает в последние годы тяжелые времена. Это и резкое сокращение приема, и устаревание лабораторной базы, и нарастающая бюрократизация учебного процесса, и недофинансирование, и сокращение приема в аспирантуру, возросшие трудности с открытием ученых советов по защите диссертаций, и, как следствие, разрыв в некогда естественном процессе сменяемости поколений вузовских научных школ. Проблемы эти во многом не регионального, а федерального уровня, но ложатся они тяжелым бременем именно на регионы.

Очень важным направлением деятельности по наращиванию человеческого капитала является развитие системы дополнительного образования, позволяющей жителям области повышать свою квалификацию и проходить профессиональную переподготовку. Этим активно занимаются и административные структуры региона, и учреждения высшего образования. 
Правительство Ивановской области проводит активную политику, направленную на выведение региона из числа дотационных, да еще и обремененных тревожными демографическими показателями. Основные направления этой политики будут рассмотрены в следующем разделе.

\section{5. Внешняя и внутренняя политика}

Ивановская область активно включилась в программу создания комфортной городской среды, прежде всего в самом Иванове. Результаты этой деятельности уже видны, особенно на примере реконструированных площадей Ленина, Победы и привокзальной. Последнюю реконструировали вместе с железнодорожным вокзалом, не просто похорошевшим в результате основательного ремонта, но и ставшим оригинальным культурным пространством.

Еще одно активно развиваемое направление связано с поддержкой исторических поселений и малых городов. В 2019 году существенно преобразился облик Палеха. В 2021 году начнутся работы в Юрьевце и Гавриловом Посаде. По итогам Всероссийского конкурса еще четыре гранта получили города Шуя, Кинешма, Южа и Тейково. Ивановская область вошла в тройку лидеров России по объему поддержки исторических поселений и малых городов.

Очень важное направление политики правительства региона связано с территориями опережающего социально-экономического развития (далее-ТОСЭР) в моногородах Ивановской области. Область вошла в число регионов-лидеров по реализации соглашения о создании территории опережающего социально-экономического развития. Так, за счет средств Фонда развития моногородов при софинансировании из областного бюджета построены и введены в эксплуатацию очистные сооружения при ООО «ХБК „Навтекс“» в моногороде Наволоки.

Начиная с 20 июня 2018 года в ТОСЭР «Наволоки» привлечено более 348 млн рублей и создано 963 рабочих места. По состоянию на 1 января 2020 года в реестр резидентов ТОСЭР «Наволоки» включены 3 предприятия: ООО «ХБК „Навтекс“», ООО «Техоснастка-Наволоки» и ООО «Завод акустических решений "Стандартпласт"». Начато финансирование инвестиционного проекта "Создание ткацкого производства хлопчатобумажных тканей для домашнего текстиля», реализуе мого силами ООО «Центр развития моногорода» на территории моногорода Наволоки. На региональном уровне для резидентов ТОСЭР «Южа» и «Наволоки» по налогу на прибыль установлена льгота 3\% на первые пять налоговых периодов и 11\% - на последующие пять налоговых периодов.

В целом политика правительства Ивановской области направлена, с одной стороны, на взаимодействие с правительством РФ и другими регионами РФ, развитие прямых контактов с некоторыми зарубежными странами с целью поиска инвесторов и рынков сбыта продукции, производимой в регионе; с другой стороны, это планомерная работа, направленная на решение внутренних проблем: развитие промышленности, строительства, транспорта и сельского хозяйства. Пристальное внимание направлено и на развитие социальной сферы-здравоохранения, образования, культуры, молодежной политики, социальной защиты, а также сервиса, туризма, рекреации, повышение уровня и качества жизни населения и в конечном счете - на решение в регионе проблем демографии.

\section{Заключение}

Создание бренда региона - не одномоментное действие. Это многоступенчатый, длительный и сложный процесс, который отнюдь не сводится к поиску некоего словесного определения, которое все выразит и обеспечит решение всех проблем.

Ивановская область-российский регион, который постепенно выходит из очень сложного положения, в котором он оказался в результате жесточайшего кризиса одной из обрабатывающих отраслей промышленности, в которой он на протяжении длительного времени играл ведущую роль в масштабах всей страны.

Предложенная выше бренд-платформа на основе шестиугольника С. Анхольта рассматривается нами как некое, если угодно, эмоциональное основание для успешной работы региональных элит и сообщества креативных специалистов по преодолению тяжелых последствий поразившего регион три десятилетия тому назад системного кризиса.

Основанием для надежды на успех должна стать уверенность, что от своих предков с тысячелетней историей население Ивановского региона унаследовало предприимчивость и стремление к лидер- 
ству. Эту уверенность должны разделять региональные элиты. Эту веру старшие поколения должны взращивать в среде молодежи.

Действующее ныне правительство области успешно работает над созданием привлекательного имиджа нашего региона, стремясь донести каждый позитивный сдвиг до широких слоев населения. И это, конечно же, верно и совершенно необходимо, так как успешность изменений должны чувствовать не только элиты, но и - пусть в разной степени-все слои населения региона. Иначе просто ничего не получится.

Бренд территории - это инструмент для привлечения инвесторов, специалистов, туристов, новых жителей и квалифицированных мигрантов, а также средство расширения рынка сбыта региональной продукции, установления и поддержания взаимовыгодных отношений с ближними и дальними соседями.

Сконструировать такой инструмент, научиться его использовать и постоянно настраивать под силу лишь коллективу креативных людей-специалистов, представляющих все основные сферы деятельности. Создать такой коллектив - одна из первоочередных и важнейших, на наш взгляд, задач, которую нужно решить сообществу Ивановской области.

\section{Источники}

Анхольт С., Хильдрейт Дж. (2010) Бренд Америка: мать всех брендов. М.: Добрая книга.

Анхольт С. (2004) Брендинг: дорога к мировому рынку. М.: Кудиц-Образ.

Балдин К.Е., Мокеев С.В. (2006) Развитие текстильной промышленности Ивановского края в 60-е гг. XIX - начале XX в. Иваново: Иван. гос. $\mathrm{yH}-\mathrm{T}$.

Балдин К.Е., Семененко А.М. (1996) Иваново. История и современность. Иваново: «Ивановская газета».

Белугина Г.К. (2020) Два Андрея: Андрей Рублев-Андрей Тарковский: Концепция межрегионального тематического тура // Международный и российский туризм в условиях новых вызовов. Сб. статей и кейсов. М.: Экономический факультет МГУ. С. 169-174.

Гарелин Я.П. (1884) Город Иваново-Вознесенск, или бывшее село Иваново и Вознесенский посад. В 2 4.-Иваново: Иван. гос. ун-т, 2001. Ч. 1. 240 с.-Репринт. воспроизведение изд. я.И. Борисоглебского 1884 г. (Шуя). С. 35-46. Ермолин Е.А. (2007) Ярославский стиль: монография. Ярославль: Ярославский государственный педагогический университет им. К.Д.Ушинского.

Каган Ф.И. (2008) Властелины «кольца» // Наша Родина-Иваново-Вознесенск. Спец. выпуск . C. $36-43$.
Каган Ф.И. (2010) Музей Иванов в Иванове // Музей. № 9. С. 21-25.

Каган Ф.И. (2016) Музейный квартал как актуальный тренд социокультурного развития города // Сборник публикаций научного журнала Globus по материалам VI международной научно-практической конференции: «Общественные науки в современном мире» г. Санкт-Петербурга. Спб.: Научный журнал Globus. С. 36-43.

Каган Ф.И. (2020) Региональный туризм через межрегиональный. Концепция развития на примере Ивановской области // Регионы и города России как туристские территории: условия и перспективы устойчивого развития. Сб. статей. М.: Экономический факультет МгУ. С. 3847.

Каган Ф.И., Белугина Г.К. (2013) Актуализация культурного наследия как процесс динамики культуры: монография. М.: 000 «Сам полиграфист».

Каждый пятый метр российской ткани делается в Ивановской области (2019) // ГТРК «Ивтелерадио». Режим доступа: https://ivteleradio. ru/news/2019/06/09/kazhdyy_pyatyy_metr_ rossiyskoy_tkani_delaetsya_v_ivanovskoy_ oblasti (дата обращения: 05.01.2021).

Котлер Ф., Асплунд К., Рейн И., Хайдер д. (2005) Маркетинг городов. Привлечение инвестиций, предприятий, жителей и туристов в города, коммуны, регионы и страны Европы. СПб.: Изд-во «Стокгольмская школа экономики».

Нора П. (1999) Проблематика мест памяти // Франция-память. Спб: Изд. Спбгу. С. 17-50.

Площади территорий регионов России (2019) // Всемирная география. Режим доступа: http:// worldgeo.ru/russia/lists/?id=22 (дата обращения: 12.08.2019).

Рейтинг регионов России по обеспечению цифровой открытости объектов культурного наследия (2018) // НП «Викимедиа РУ». Режим доступа: https://ru.wikimedia.org/wiki/Рейтинг_регионов_России_по_обеспечению_цифровой_открытости_объектов_культурного_наследия (дата обращения: 12.08.2019).

Скрынников Р.Г. (1997) История Российская. IX-XVII вв. М.: Издательство «Весь Мир».

Тимофеев М.ю. (2017) Иваново. Город красной зари. Неканонический путеводитель. Иваново: А-ГРИФ.

Тихомиров А.М. (2011) Иваново. Иваново-Вознесенск. Путеводитель сквозь времена. Иваново: ИД «Референт».

Тяпков Н.Н. (2018) Топонимический словарь Ивановской области: Географические названия: села и города. Иваново: ИД «Референт». 
IVANOVO REGIONAL BRANDING AS A PROBLEM AND A PROCESS

Felix I.Kagan, PhD in Physics and Mathematics; Head of the Complex of Museum, Exhibition and Rsource Centers of Ivanovo State Polytechnic University; Associate Professor of the Department of Information Technologies and Services of Ivanovo State Polytechnic University; Associate Professor; Candidate of Physical and Mathematical Sciences; Honored Worker of Culture of the Russian Federation; 21 Sheremetievsky prospect, Ivanovo, 153000, Russian Federation, tel.: +7903 8796940

E-mail: fik35@mail.ru

Abstract. This article outlines a possible approach to the rebranding of the Ivanovo region in the complex post-Soviet crisis. In the 1990s, the region found itself in a very difficult situation, burdened by acute socio-economic and demographic problems that arose during Perestroika and the post-Perestroika period during a systemic crisis in the country's textile industry. The severity of the crisis was compounded by the single-industry nature of the region, which had held a leading position in the textile industry nationwide for almost four centuries. The situation began to improve only recently, so the problem of rebranding the region has become urgent.

When building the brand platform of the Ivanovo region, the author relies on the "Anholt brand hexagon", which combines indicators for six areas: (1) the image/ brand archive, (2) the historical and cultural heritage, (3) business, investment and migration,

(4) inbound and domestic tourism, (5) human capital, (6) domestic and foreign policy. While carrying out the content of this scheme the author takes into account the socio-economic and historical-cultural specifics of the Ivanovo region. He conducts a detailed analysis of the history of the images and positioning of this region from the 17th to 20th centuries, which gives historical depth to the analysis of the current state and prospects for the development of the region. Possible ways of developing its tourism sector are outlined.

Key words: Ivanovo region; region branding; brand platform; Anholt hexagon
Citation: Kagan F.I. (2021) Ivanovo Region Branding as a Problem and a Process. Urban Studies and Practices, vol. 6, no 1, pp. 6-22. (in Russian) DOI: https://doi.org/10.17323/ usp6120216-22

\section{References}

Anholt S., Hildreth D. (2010) Brand Amerika: mat' vseh brendov [Brand America: The Mother of All Brands]. Moskva: Dobraja kniga [Moscow: Kind Book]. (in Russian) Anholt S. (2004) Brending: doroga k mirovomu rynku [Branding: Way to the World Market]. M.: KudicObraz. (in Russian)

Baldin K.E., Mokeev S.V. (2006) Razvitie tekstil'noj promyshlennosti Ivanovskogo kraja v 60-e gg. $X I X$-nachale XX $\vee$ [Development of the Textile Industry of the Ivanovo Region in the $60 \mathrm{~s}$ of the XIX-early XX Century]. Ivanovo: Ivan. gos. un-t [Ivanovo: Ivanovo State University]. (in Russian)

Baldin K.E., Semenenko A.M. (1996) Ivanovo. Istorija $i$ sovremennost' [Ivanovo. History and Contemporaneity]. Ivanovo: «Ivanovskaja gazeta» [Ivanovo: Ivanovo Newspaper]. (in Russian)

Belugina G.K. (2020) Dva Andreja: Andrej Rublev-Andrej Tarkovskij: Koncepcija mezhregional'nogo tematicheskogo tura [Two Andreys: Andrey Rublev-Andrey Tarkovsky: The Concept of an Interregional Thematic Tour]. Mezhdunarodnyj $i$ rossijskij turizm $v$ uslovijah novyh vyzovov. Sb. statej $i$ kejsov [International and Russian Tourism in the Conditions of New Challenges. Collection of Articles and Cases]. Moskva: Jekonomicheskij fakul'tet MGU [Moscow: Faculty of Economics of Moscow State University], pp. 169-174. (in Russian)

Garelin Ya.P. (1884) The city of Ivanovo-Voznesensk, or the former village of Ivanovo and Voznesensky posad. At $2 \mathrm{pm}$-Ivanovo: Ivan. State un-t, 2001. Part 1. 240 p. Reprint. Reproduction ed. Borisoglebskiy 1884 (Shuya), pp. 35-46. (in Russian)

Ermolin E.A. (2007) Jaroslavskij stil': monografija [Yaroslavl style: monograph]. Jaroslavl': Jaroslavskij gosudarstvennyj pedagogicheskij universitet im. K.D. Ushinskogo [Yaroslavl: Yaroslavl State Pedagogical University named after K.D. Ushinsky]. (in Russian)

Kagan F.I. (2008) Vlasteliny "kol'ca" [The Lords of the "Ring"]. Nasha Rodina Ivanovo-Voznesensk. Special'nyj vypusk [Nasha Rodina
Ivanovo-Voznesensk. Special issue], pp. 36-43. (in Russian) Kagan F.I. (2010) Muzej Ivanov v Ivanove [Museum of Ivans in Ivanovo]. Muzej [Museum], no 9, pp. 21-25. (in Russian)

Kagan F.I. (2016) Muzejnyj kvartal kak aktual'nyj trend sociokul'turnogo razvitija goroda [Museum Quarter as an Actual Trend of Socio-Cultural Development of the City]. Sbornik publikacij nauchnogo zhurnala "Globus" po materialam VI mezhdunarodnoj nauchno-prakticheskoj konferencii: «Obshhestvennye nauki $v$ sovremennom mire» g. Sankt-Peterburga. [Collection of Publications of the Scientific Journal "Globus" Based on the Materials of the VI International Scientific and Practical Conference: "Social Sciences in the Modern World" of St.Petersburg]. St.Petersburg: Nauchnyj zhurnal "Globus" [St. Petersburg: Scientific journal "Globus"], pp. 3643. (in Russian)

Kagan F.I. (2020) Regional'nyj turizm cherez mezhregional'nyj. Koncepcija razvitija na primere Ivanovskoj oblasti [Regional Tourism through Interregional. The Concept of Development on the Example of the Ivanovo Region]. Regiony $i$ goroda Rossii kak turistskie territorii: uslovija $i$ perspektivy ustojchivogo razvitija. Sb.Statej [Regions and Cities of Russia as Tourist Territories: Conditions and Prospects of Sustainable Development. Collection of Articles]. Moscow: Jekonomicheskij fakul'tet MGU [Moscow: Faculty of Economics of Moscow State University], pp. 38-47. (in Russian)

Kagan F.I., Belugina G.K. (2013) Aktualizacija kul'turnogo nasledija kak process dinamiki kul'tury: monografija [Actualization of Cultural Heritage as a Process of Culture Dynamics: Monograph]. Moscow: 000 «Sam poligrafist». (in Russian)

Kazhdyj pjatyj metr rossijskoj tkani delaetsja $v$ Ivanovskoj oblasti (2019) [Every Fifth Meter of Russian Fabric is Made in the Ivanovo Region]. GTRK «Ivteleradio». Available at: https://ivteleradio.ru/news/2019/ 06/09/kazhdyy_pyatyy_metr_rossiys koy_tkani_delaetsya_v_ivanovskoy_ oblasti (accessed 05 January 2021). (in Russian)

Kotler F., Asplund K., Rejn I., Hajder D. (2005) Marketing gorodov. Privlechenie investicij, predprijatij, zhitelej i turistov 
$v$ goroda, kommuny, regiony i strany Evropy [Marketing of Cities. Attracting Investments, Enterprises, Residents and Tourists to Cities, Communes, Regions and Countries of Europe]. St.Petersburg: Izd-vo «Stokgol'mskaja shkola jekonomiki» [St. Petersburg: Publishing House "Stockholm School of Economics".]. (in Russian)

Nora P. (1999) Problematika mest pamjati [Problematics of Places of Memory]. Francija-pamjat' [Francememory]. St. Petersburg: Izd. SPbGU [St. Petersburg: St. Petersburg State University Publishing House], pp. 17-50

Ploshhadi territorij regionov Rossii (2019) [Areas of the Regions of Russia]. Vsemirnaja geografija
[World Geography]. Available at: http://worldgeo.ru/russia/

lists/?id=22 (accessed 12 August 2019). (in Russian)

Rejting regionov Rossii po obespecheniju cifrovoj otkrytosti ob非k tov kul'turnogo nasledija (2018) [Rating of Russian Regions for Ensuring Digital Openness of Cultural Heritage Objects]. NP «Vikimedia RU». Available at: https:// clck.ru/EyJYL (accessed 12 August 2019). (in Russian)

Skrynnikov R.G. (1997) Istorija Rossijskaja. IX-XVII vv. [Russian history. IX-XVII Centuries.] Moskva: Izdatel'stvo "Ves' Mir» [Moscow: Publishing House «All the World»]. (in Russian)
Tihomirov A.M. (2011) Ivanovo. Ivanovo-Voznesensk. Putevoditel' skvoz' vremena [Ivanovo. IvanovoVoznesensk. A Guide through Time]. Ivanovo: ID «Referent». (in Russian)

Timofeev M.J. (2017) Ivanovo. gorod krasnoj zari. Nekanonicheskij putevoditel' [Ivanovo. The City of the Red Dawn. A Non-Canonical Travel Guide]. Ivanovo: A-GRIF. (in Russian)

Tjapkov N.N. (2018) Toponimicheskij slovar' Ivanovskoj oblasti: Geograficheskie nazvanija: sela i goroda [Toponymic Dictionary of the Ivanovo Region: Geographical Names: Villages and Cities]. Ivanovo: ID "Referent". (in Russian) 